\title{
Size, imbibition, and viability of seeds of two creole melon (Cucumis melo L.) from the state of Guerrero, Mexico
}

Escobar-Álvarez, José L. ${ }^{1}$, Ramírez-Reynoso, Omar ${ }^{2}$, Sánchez-Santillán, Paulino ${ }^{3}$, Cuellar-Olalde, Rocío ${ }^{1}$, Romero Rosales, Teolincacíhuatl ${ }^{4}$, Valenzuela-Lagarda, José L. ${ }^{2}$

${ }^{1}$ Universidad de Colima, Facultad de Ciencias Biológicas y Agropecuarias, Tecomán, Colima, México. ${ }^{2}$ Universidad Autónoma de Guerrero, Centro Regional de Educación Superior de la Costa Chica, Florencio Villarreal, Guerrero, México. ${ }^{3}$ Universidad Autónoma de Guerrero, Facultad de Medicina Veterinaria y Zootecnia No. 2, Cuajinicuilapa, Guerrrero, México. ${ }^{4}$ Universidad Autónoma de Guerrero, Facultad de Ciencias Agropecuarias y Ambientales, Iguala, Guerrero, México.

Corresponding Author: joseluislagarda@uagro.mx

\section{ABSTRACT}

Objective: To determine the physical and physiological characteristics of Creole melon seeds from the Costa Chica of Guerrero

Design/Methodology/Approach: It was established under a completely randomized design, and Student's t-test ( $\alpha=0.05)$ and correlation with Pearson's test were performed. Viability and imbibition were carried out using the methodologies described by the International Seed Testing Association (ISTA).

Results: Creole seeds of the two varieties presented a significant statistical difference (95\% confidence level) in the physical quality variables. The imbibition ended at 18 and $32 \mathrm{~h}$ in $V_{2}$ and $V_{1}$, respectively, after being submerged in water. The humidity percentage was higher in $V_{1}$ (7.19); while, $V_{2}$ presented a higher percentage of germination and viability (96 and $90 \%$, respectively). There is a positive association between the humidity and the physical dimensions of the seed and the germination and viability $\left(r^{2}=0.954\right)$ that is highly significant $(P=0.003)$.

Study Limitations/Implications: Morphological and taxonomic classification studies of the Creole genotypes of the Costa Chica region of Guerrero are required.

Findings/Conclusions: There was a positive correlation between the physical and physiological quality of the Creole melon seeds.

Keywords: Correlation, Germination, Seeds, Tetrazolium.

\section{INTRODUCTION}

Melon

(Cucumis melo L.) is a species in the Cucurbitaceae family and is originally from Asia and Africa (Mehra et al., 2015). This family includes more than 900 species, among which 10 genera are of economic importance, mainly including cucumbers and melons (Cucumis sp), squashes and zucchinis (Cucurbita sp.), and watermelons (Citrullus lanatus L.) (Paris et al., 2017). Melon is considered one of the most diverse

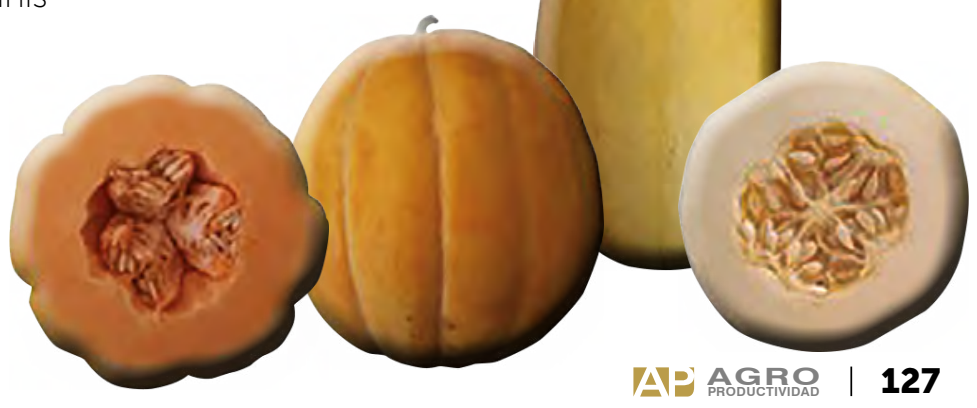


species within the Cucumis genus due to its extensive genotypic and phenotypic variation (Farcuh et al., 2019). The 16 recognized melon groups have merged, five of them being divided into the subspecies agrestis and 11 into the subspecies melo, including the cantalupensis (cantaloupe), reticulatus (muskmelon) and inodorus (honeydew) groups (Assis-Dantas et al., 2015).

Commercially, melon is one of the most important horticultural crops in México due to the surface area farmed and production volume (Monge-Pérez, 2013). In Guerrero, melon farming is economically important: in 2019, 99,862 t were produced with a yield of 29.66 Ton $\mathrm{ha}^{-1}$ (SIAP, 2019). Additionally, traditional production systems subsist in the state where native varieties are conserved in situ and gathered species are also used (Vera-Sánchez et al., 2016).

The main method of melon propagation is by seed, which generates high demand for quality seeds that should have different attributes including genetic, physiological, physical, and sanitary quality (Basra, 1995; Copeland and McDonald, 1995). For this purpose, characteristics such as fidelity to the variety, germination percentage, purity, vigor, appearance, and absence of disease are considered, since they contribute to a higher productive varietal efficiency and the ability to sprout quickly and uniformly under different environmental conditions (Finch-Savage and Bassel, 2016). Germination and viability tests have been widely used in seed evaluation (Villa et al., 2019). Therefore, the objective of the present study was to collect seeds in the municipality of Florencio Villareal in the state of Guerrero to determine the physical and physiological characteristics of Creole melon (Cucumis melo L.) seeds.

\section{MATERIALS AND METHODS}

The collection site was in the region of Costa Chica, in the municipality of Florencio Villareal, located in the southern part of the state of Guerrero ( $16^{\circ} 43^{\prime} 26^{\prime \prime}$ LN y $99^{\circ} 07^{\prime} 24^{\prime \prime}$ LW). The varieties were classified according to the fruit's shape; $V_{1}$ were round, corrugated or segmented fruits, and $V_{2}$ were elongated and smooth fruits, commonly known as cucumber-melons. After collecting, the seeds were washed to eliminate pulp residues and placed on drying paper to eliminate water excess. Later, they were sent in hermetically sealed, labeled containers to the Multidisciplinary Laboratory of the Faculty of Biological and Agricultural Sciences at the University of Colima, located in the municipality of Tecomán, Colima.

\section{Physical Characterization}

The physical quality of the seeds was determined by their size (Pérez-Mendoza et al., 2016). The variable studied was the weight of 1000 seeds (WTS), which was estimated by weighing 100 seeds in eight repetitions and calculating the average, typical deviation, and variation coefficient that resulted in $\geq 3.1 \%$, then the average was multiplied by 10 (ISTA, 1996). The seed length (SL), width (SW), and thickness (ST) were measured with a digital caliper $\left(\right.$ Truper $\left.^{\circledR}\right)$, and the ratio between seed length and width (LWR) was calculated. The humidity content was determined with the stove method (ISTA, 2014) at $70{ }^{\circ} \mathrm{C}$ for 72 hours, and 25 complete seeds were used with three repetitions. The weight was recorded in an analytical balance (Sartorius ${ }^{\circledR}$, BP221S), and calculations were made based on the fresh weight (Poulsen, 2000; Lezcano et al., 2007). The humidity content $\left(H_{C}\right)$ was calculated with Eq. 1 and expressed in percentage, were $H_{C}=$ humidity content, $W_{1}=$ weight of the container expressed in $\mathrm{g}, W_{2}=$ initial container and seed weight (g) and $W_{3}=$ final container and seed weight $(\mathrm{g})$.

$$
H_{C}=\left(W_{1}-W_{3}\right) * \frac{100}{\left(W_{1}-W_{2}\right)} \quad \text { Eq. } 1
$$

\section{Imbibition Kinetics}

Using an analytical balance (Sartorius ${ }^{\circledR}$, BP221S), $25 \mathrm{~g}$ of seeds of each variety were weighed. Later, they were submerged in distilled water for $36 \mathrm{~h}$ at room temperature $\left(23 \pm 2^{\circ} \mathrm{C}\right)$. The increase in weight was registered every two $h$ and the amount of water absorbed was expressed through Eq. 2, where $W_{a d}=$ water adsorbed, $W_{i}=$ initial weight, $W_{f}=$ final weight, and $H_{i}=$ humidity content (Domínguez-Domínguez et al., 2007).

$$
W_{a d}=\frac{W_{f}-W_{i}}{W_{i}\left(1-\frac{H_{i}}{100}\right)}
$$

\section{Physiological Quality in the Laboratory}

The standard germination test (SGT) was carried out according to the ISTA rules (2014) with modifications. Fifty seeds were distributed in five rows in a transparent polyethylene clamshell with a layer of cotton previously moistened with distilled water. These were then placed inside a germination chamber at temperature of $25 \pm 2{ }^{\circ} \mathrm{C}$. Counting started from the first day and germination was calculated using Eq. 3 and expressed as 
a percentage, where GP = germination percentage, $n$ i = total germinated seeds, and $N=$ total seeds sampled.

$$
G P(\%)=\frac{n i}{N} * 100 \quad \text { Eq. } 3
$$

The germination speed index (GSI) was obtained through the methodology proposed by Maguire (1962) and Martínez-Solís et al. (2010). Germinated seeds were counted daily, seeds with sprouted radicles were considered, and Eq. 4 was applied, where GSI = germination speed index, $\mathrm{Ti}=$ time in hours passed between the test start and the end of the interval, and $\mathrm{Ni}$ = number of germinated seeds within consecutive time intervals.

$$
G S I=\sum \frac{N i}{T i} \quad \text { Eq. } 4
$$

The coefficient of germination speed (CGS) is a distribution measure based on the number of germinated seeds through time and the number of germinated seeds per day (González-Zertuche and Orozco-Segovia, 1996), and was determined by Eq. 5, proposed by Kotowski (1926), where CGS = coefficient of speed, $n=$ number of seeds germinated per day $i$, and $t=$ number of days since planting.

$$
C G S=\frac{\sum n i}{\sum(n i T i)} * 100
$$

The viability analysis ( $V$ ) was done with the technique involving tetrazolium chloride, described by ISTA (2014) and Maldonado-Peralta et al. (2016). One-hundred seeds were placed in an uncovered jar with distilled water, and this was put in a water bath at a temperature of $35^{\circ} \mathrm{C}$ for 14 hours. Later, a $1 \%$ tetrazolium chloride solution was added, and the jar of seeds was put in a water bath at a temperature of $35^{\circ} \mathrm{C}$ for $4 \mathrm{~h}$. Finally, the seeds were rinsed with distilled water and examined under a stereoscopic microscope (LEICA, EZR ${ }^{\circledR}$ ). The embryos were classified according to color intensity: 1) alive with high vigor, when they were completely dyed with an intense red color, 2) alive with low vigor, when their coloration was a pale red, and 3) not viable, when they remained colorless. This was expressed as the percentage of viable and unviable embryos.

\section{Data Analysis}

The data obtained for each measured variable in percentages was transformed with the $\operatorname{Arcsine} \sqrt{x / 100}$ formula and the averages were compared in pairs using the Student's t-test $(\alpha=0.05)$. For all the physical and physiological characteristics evaluated in the seeds, a correlational analysis was done with the Pearson test $(\alpha=0.05)$, using the MINITAB 18 statistical software.

\section{RESULTS AND DISCUSSION}

\section{Physical Characterization}

The analysis demonstrated statistical differences $(P<0.0001)$ in seed size among varieties, except in the length/width ratio, which was statistically equal $(P=0.427)$. Concerning the weight of 1000 seeds, $V_{1}$ was statistically different $(P<0.0001)$ from $V_{2}$ (Table 1 ). Mansouri et al. (2017) reported average values of 7.75 , 3.50, and $1.00 \mathrm{~mm}$ in length, width, and thickness, respectively. The weight of 1000 seeds fluctuated between 40.66 and $49.57 \mathrm{~g}$, similar to the weight of $V_{2}$ in this study.

Karayel et al. (2004) evaluated the uniformity of a seeder with different vacuum pressures on different seeds. The averages found in melon seeds were $11.44 \mathrm{~mm}$ in length, and 4.62 and $2.35 \mathrm{~mm}$ in width and thickness, respectively, while the weight of 1000 seeds without coats (testa) was $36.70 \mathrm{~g}$. The physical attributes of seeds are important for calculating the surface area and volume of the grains to model the storage and design of separation equipment (Sologubik et al., 2013; Mansouri

\begin{tabular}{|c|c|c|c|c|c|}
\hline Variety & $\mathrm{SL}(\mathrm{mm})$ & $\mathrm{SW}(\mathrm{mm})$ & TS (mm) & LWR & W1000s (g) \\
\hline$V_{1}$ & $10.97 \pm 0.21^{a}$ & $5.06 \pm 0.04^{a}$ & $1.74 \pm 0.05^{a}$ & $2.16 \pm 0.05^{a}$ & $172.3 \pm 13^{a}$ \\
\hline$V_{2}$ & $6.26 \pm 0.11^{b}$ & $2.82 \pm 0.05^{b}$ & $1.38 \pm 0.02^{b}$ & $2.21 \pm 0.08^{a}$ & $41.27 \pm 1.27^{b}$ \\
\hline p value & $<0.0001$ & $<0.0001$ & $<0.0001$ & 0.427 & $<0.0001$ \\
\hline C.V. & 1.95 & 1.37 & 2.66 & 3.36 & 8.66 \\
\hline
\end{tabular}
et al., 2017), as well as agricultural implements (Karayel et al., 2004).

Means \pm standard deviation with different literals is statistically different with a confidence level of $95 \%$ (Student's t). SL $=$ seed length. SW = seed width. TS = thickness of seeds. LWR $=$ length $/$ width ratio. W1000s $=$ weight of one thousand seeds. C.V. $=$ coefficient of variation. 


\section{Imbibition Kinetics}

Figure 1 shows the imbibition curve of Creole melon seeds, in which within the first two hours, the water adsorbed by the seed increased in weight by approximately $56 \%$ in $V_{1}$ and by $42 \%$ in $V_{2}$, which constitutes the first phase of imbibition (Suárez and Melgarejo, 2010). Domínguez-Domínguez et al. (2007), for their part, found the first phase in hibiscus seeds (H. sabdariffa L.) between the first six and $10 \mathrm{~h}$. These authors explain that, since they are irregular geometric bodies, the speed of water transference to the interior cannot solely be explained by geometric variables, such as the volume to surface area ratio.

Teixeira Pinheiro et al. (2016) report that melon seeds induced to saline stress in different imbibition times, increase enzymatic activity and decrease germination rates. In the end, $V_{1}$ seeds stopped water absorption after $32 \mathrm{~h}$, while $V_{2}$ after $18 \mathrm{~h}$, at which time the biochemical activity begins and the radicle appears (Maynard, 2007).

\section{Physiological Quality}

Table 2 shows that the percentage of humidity and germination were statistically different between $V_{1}$ and $V_{2}(P=0.010$ and $P=0.030$, respectively); viability, speed index and coefficient were statistically equal ( $P \geq 0.065$ ). Barros-Torres and Marcos-Filho (2003) evaluated the humidity content in different lots of two melon hybrids and noted it fluctuated between 7.0 and $7.3 \%$, while in this study, $V_{2}$ was reported to have a lower content (5.77\%). These same authors indicate that the variation in humidity content of the seeds is probably due to their size. Casenave and Toselli (2010) reported that in 'Honeydew' melon seeds subjected to different conditions of water stress, germination was $\leq 94 \%$, and they indicate that by modifying the water potential, the percentage of germination was reduced in the seeds.

Nery et al. (2007) reported that in seeds of five watermelon cultivars (C. lanatus L.), germination values were 39\% in a triploid hybrid and from 89 to $99 \%$ in diploids. Of viable seeds, the triploid hybrid presented $83 \%$ and the diploids $>98 \%$, similar values to those obtained in this study. The quality of $C$. Lanatus $L$. seeds could be low in hybrids (triploids compared to diploids) due to the time they take to germinate and that they present embryonic malformation problems from chromosomal alterations necessary to avoid seed formation (Souza et al., 1999; Grangem et al., 2003; Nery et al., 2007). The speed index, reported by these same authors, was $>2.24$;

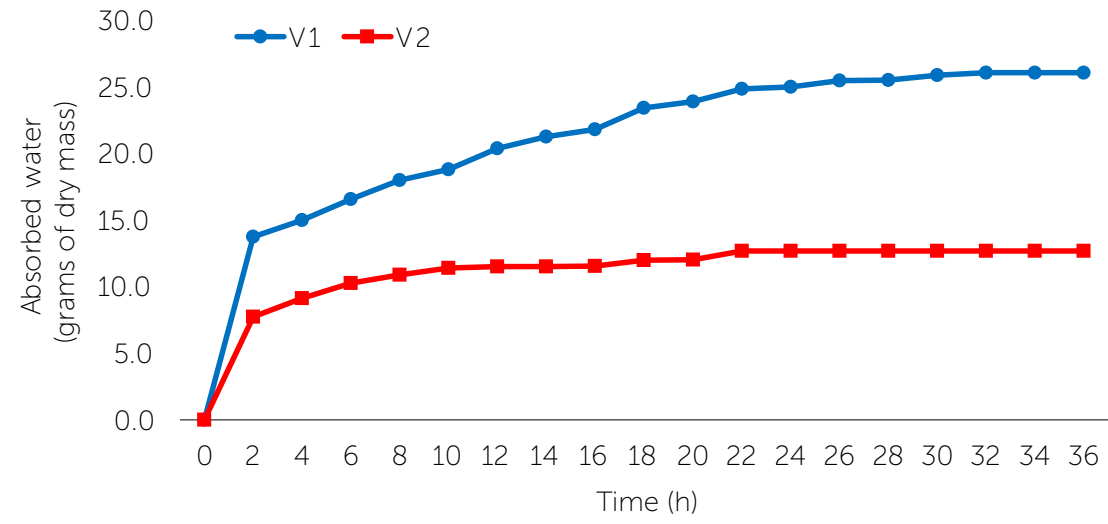

Figure 1. Imbibition curves of two varieties of Creole melon (Cucumis melo L.) seeds from the Costa Chica region of Guerrero, Mexico. while in $V_{1}$ melon seeds, it was 2.24, and in $V_{2}$ it was 2.08. Concerning the speed coefficient, $44 \%$ and $48 \%$ of $V_{1}$ and $V_{2}$ seeds, respectively, germinated per day. In Arachis hypogaea L. genotypes, Caroca et al. (2016) found that GSI varies from 2.94 to 20.84 due to the effect of temperature, and they note that seeds exposed to high temperatures (>32 $\left.{ }^{\circ} \mathrm{C}\right)$ are negatively affected in germination speed.

Regarding the viability analysis, the results obtained showed that $78 \%$ and $90 \%$ (Table 2) of $V_{1}$ and $V_{2}$ seeds, respectively,

\begin{tabular}{|c|c|c|c|c|c|}
\hline Variedades & $H(\%)$ & GP (\%) & V (\%) & GSI & CGS \\
\hline$V_{1}$ & $7.19 \pm 0.27^{a}$ & $84.0 \pm 6.0^{b}$ & $78.0 \pm 8.0^{a}$ & $2.24 \pm 0.18^{a}$ & $0.44 \pm 0.03^{a}$ \\
\hline$V_{2}$ & $5.77 \pm 0.46^{b}$ & $96.0 \pm 2.0^{a}$ & $90.0 \pm 2.0^{a}$ & $2.08 \pm 0.07^{a}$ & $0.48 \pm 0.01^{a}$ \\
\hline$p$ value & 0.010 & 0.030 & 0.065 & 0.230 & 0.227 \\
\hline C.V. & 5.89 & 4.97 & 6.94 & 5.37 & 5.98 \\
\hline
\end{tabular}

Means \pm standard deviation with different literals is statistically different with a confidence level of $95 \%$ (Student's t). $H=$ humidity. $\mathrm{GP}=$ germination percentage. $\mathrm{V}=$ viability. $\mathrm{GSI}=$ germination speed index. $\mathrm{CGS}=$ coefficient of germination $\mathrm{speed}$. $\mathrm{CV}=$ coefficient of variation. 
presented complete staining of the embryo and cotyledons (Figure 2A and $2 \mathrm{C}$ ), indicating that they were alive; while Figure $2 \mathrm{~B}$ and $2 \mathrm{C}$ show the unviable seeds that were not stained by the tetrazolium.

Barone et al. (2016) report that the greatest difficulty to ensure good interpretation of results is finding an adapted protocol; although it has been used in different species, there are limited reports on melon seeds.

However, Inácio-Barros et al. (2005) showed that the tetrazolium test is efficient to determine the viability of squash seeds, finding between 59 and 100\% of viable seeds among different batches. Another factor that influences viability is the age of the seed. Enríque-Peña et al. (2004) reported that seeds of Taxodium mucronatum (Ten.) presented an average reduced viability of $63 \%$ after 21 months in storage.

\section{Correlation Analysis}

A high positive correlation $\left(r^{2}>0.859\right)$ was found between humidity and length, width, and thickness, and P1000s (Table 3). Concerning the germination percentage, it presented $r^{2}=0.954$ with high significance $(P=0.003)$, where a trend or increase was observed between germination and viability, and with these results, the yield potential of the studied varieties can be predicted (Panwar et al., 2018). Likewise, the physical characteristics of the seeds showed positive correlations, indicating that weight is influenced by the seed dimensions (Table 3). Nuraini et al. (2018) suggested that associations in seed quality, specifically seed weight, are useful for improving the existing varieties and developing new genotypes.

A negative correlation $\left(r^{2}=-0.868\right)$ was found between humidity and germination, where it was observed that the higher the humidity content, the lower the germination percentage. This could be explained with Table 1, where

\begin{tabular}{|c|c|c|c|c|c|c|c|c|c|}
\hline & $H(\%)$ & GP (\%) & GSI & CGS & $V(\%)$ & w1000s (g) & $\mathrm{SL}(\mathrm{mm})$ & AS (mm) & $\mathrm{TS}(\mathrm{mm})$ \\
\hline \multirow{2}{*}{$P G(\%)$} & $-0.868^{*}$ & & & & & & & & \\
\hline & $0.025^{\star \star}$ & & & & & & & & \\
\hline \multirow{2}{*}{ GSI } & 0.591 & - & & & & & & & \\
\hline & 0.217 & - & & & & & & & \\
\hline \multirow{2}{*}{ CGS } & -0.574 & - & -0.998 & & & & & & \\
\hline & 0.234 & - & 0.001 & & & & & & \\
\hline \multirow{2}{*}{$V(\%)$} & - & 0.954 & - & - & & & & & \\
\hline & - & 0.003 & - & - & & & & & \\
\hline \multirow{2}{*}{ W1000s (g) } & 0.895 & -0.865 & 0.516 & -0.517 & - & & & & \\
\hline & 0.016 & 0.026 & 0.294 & 0.293 & - & & & & \\
\hline \multirow{2}{*}{ LS (mm) } & 0.903 & -0.828 & 0.581 & -0.586 & $=$ & 0.987 & & & \\
\hline & 0.014 & 0.042 & 0.227 & 0.221 & - & 0.001 & & & \\
\hline \multirow{2}{*}{ AS (mm) } & 0.921 & -0.858 & 0.554 & -0.555 & - & 0.996 & 0.996 & & \\
\hline & 0.009 & 0.029 & 0.254 & 0.253 & - & 0.001 & 0.001 & & \\
\hline \multirow{2}{*}{ TS (mm) } & 0.859 & -0.743 & 0.512 & -0.525 & - & 0.969 & 0.990 & 0.979 & \\
\hline & 0.028 & 0.091 & 0.299 & 0.285 & - & 0.001 & 0.001 & 0.001 & \\
\hline
\end{tabular}

* Pearson's correlation coefficient $(\alpha=0.05)$. ${ }^{*} \mathrm{p}$ values with a confidence level of $95 \%$. GP $=$ germination percentage. $V=$ viability. GSI $=$ germination speed index. CGS = coefficient of germination speed. $S L=$ seed length. SW = seed width. TS $=$ thickness of seeds. LWR $=$ length / width ratio. $\mathrm{W} 1000 \mathrm{~s}=$ weight of one thousand seeds. C.V. $=$ coefficient of variation 
seeds of $V_{1}$ showed a greater humidity percentage and a lower germination percentage compared to $V_{2}$, which was the inverse. The physical characteristics showed a significant negative association with the germination percentage. The speed index and coefficient presented $r^{2}=-0.998$ with $P=0.001$ as an inverse value; that is, the higher the germination average per day, the lower the value obtained for the Kotowski index (speed coefficient) (González-Zertuche and Orozco-Segovia, 1996).

\section{CONCLUSIONS}

The physical and physiological characteristics among varieties showed differences in seed dimensions and weight. Concerning the physiological variables, $V_{2}$ presented $>90 \%$ in germination and viability, which are tools used for genetic improvement and increased yield in the field.

\section{REFERENCES}

Assis-Dantas, A.C., Araújo-Holanda, L.S., Esteras, C., Sousa-Nunes, G.H., and Pico, M.B. 2015. Diversity of melon accessions from northeastern Brazil and their relationships with germplasms of diverse origins. Journal of the American Society for Horticultural Science. 140(5):1-17

Barone, J., Duarte, E. y Luna, C. 2016. Determinación de la eficacia de métodos de evaluación de calidad de semillas de especies forestales nativas de la Selva Atlántica. Quebracho-Revista de Ciencias Forestales. 24(1-2):70-80

Barros-Torres, S. and Marcos-Filho J. 2003. Accelerated aging of melon seeds. Scientia Agricola. 60(1):77-82

Basra, A. S. 1995. Seed quality; basic mechanisms and agricultural implications. Basra, A. S. (ed.) Food Products Press. Preface. New York, USA

Caroca, R., Zapata, N. y Vargas, M. 2016. Efecto de la temperatura sobre la germinación de cuatro genotipos de maní (Arachis hypogaea L.). Chilean Journal of Agricultural \& Animal Science. 32(2): 94-101.

Casenave, E.C. \& Toselli, M.E. 2010. Germination of melon seeds under water and heat stress: Hydropriming and the hydrotime model. Seed Science \& Technology. 38:409-420

Copeland, L. O. and McDonald, M. B. 1995. Principles of seed science and technology. 3rd. ed. Chapman and Hall. New York, USA $409 \mathrm{p}$

Dominguez-Domínguez, S., Domínguez-López, A., González-Huerta, A., Navarro-Galindo, S. 2007. Cinética de imbibición e isotermas de adsorción de humedad de la semilla de jamaica (Hibiscus sabdariffa L.). Revista Mexicana de Ingeniería Química. 6(3):309-316

Enríquez-Peña, E. G., Suzán-Azpiri, H. y Malda-Barrera. G. 2004. Viabilidad y germinación de semillas de Taxodium mucronatum (Ten.) en el estado de Querétaro, México. Agrociencia. 38:375-381.

Farcuh, M., Copes, B., Le-Navenec, G., Marroquín, J., Jaunet, T., ChiJam, C., Cantu, D., Bradford, K. J., \& Deynze, A. V. 2019. Texture diversity in melon (Cucumis melo L.): Sensory and physical assessments. Postharvest Biology and Technology. 159:1-9
Finch-Savage, W. E., \& Bassel, G.W. 2016. Seed vigour and crop establishment: Extending performance beyond adaptation Journal of Experimental Botany. 67(3), 567-591.

González-Zertuche, L. y Orozco-Segovia, A. 1996. Métodos de análisis de datos de germinación de semillas, un ejemplo: Manfreda brachystachya. Boletín de la Sociedad Botánica de México. 58:15-30

Grangem, S., Leskovar, D., Pike, L. M. \& Cobb, B. G. 2003. Seed coat structure and oxygen enhanced environments affect germination of triploid watermelon. Journal of the American Society for Horticultural Science. 128(2):253-259

Inácio-Barros, D., Fernandes dos Santos Dias, D.C., Bhering, M.C., dos Santos Dias, L.A., y Fontes Araújo, E. 2005. Uso do teste de tetrazólio para avaliação da qualidade fisiológica de sementes de abobrinha. Revista Brasileira de Sementes. 27(2):165-171

ISTA. (1996). International Rules for Seed Testing. International Seed Testing Association (ISTA). Seed Science \& Technology. 24 (suppl): 243 p

ISTA. (2014). International Rules for Seed Testing. The International Seed Testing Association (ISTA). P.O. Box 308, 8303 Bassersdorf CH-Switzerland, ISBN: 3-906549-38-0

Karayel, D., Barut, Z.B. \& Özmerzi, A. 2004. Mathematical modelling of vacuum pressure on a precision seeder. Biosystems Engineering. 87(4):437-444

Kotowski, F. 1926. Temperature relations to germination of vegetable seed. Proceedings of the American Society for Horticultural Science. 23:176-184

Lezcano, J.C., Navarro, M., González, Y. y Alonso, O. 2007 Determinación de la calidad de las semillas de Leucaena leucocephala cv. Perú almacenadas al ambiente. Pastos y Forrajes. 30(1):107-118

Maguire, J. D. 1962. Speed of germination-aid in selection and evaluation for seedling emergences and vigor. Crop Science, 2:176-177.

Maldonado-Peralta, M.A., García de los Santos, G., García-Nava, J.R. Ramírez-Herrera, C., Hernández-Livera, A., Valdez-Carrasco, J.M., Torres-Corona, T. y Cetina-Alcalá, V.W. 2016. Seed viability and vigour of two nanche species (Malpighia mexicana and Byrsonima crassifolia). Seed Science \& Technology. 44:1-9.

Mansouri, A., Mirzabe, A.H. and Ráufi, A. 2017. Physical properties and mathematical modeling of melon (Cucumis melo L.) seeds and kernels. Journal of the Saudi Society of Agricultural Sciences. 16(3):218-226

Martínez-Solís, J., Virgen-Vargas, J., Peña Ortega, M.G. y SantiagoRomero, A. 2010. Índice de velocidad de emergencia en líneas de maíz. Revista Mexicana de Ciencias Agrícolas. 1(3):289-304

Maynard, L. 2007. Cucurbit Crop Growth and Development Conference Proceedings, Indiana CCA. 11 p.

Mehra, M., Pasricha, V. \& Gupta, R.J. 2015. Estimation of nutritional, phytochemical and antioxidant activity of seeds of musk melon (Cucumis melo L.) and watermelon (Citrullus lanatus L.) and nutritional analysis of their respective oils. Journal of Pharmacognosy and Phytochemistry. 3(6):98-102.

Monge-Pérez, J. E. 2013. Producción y exportación de melón (Cucumis melo) en Costa Rica. Tecnología en Marcha 27(1): 93-103.

Nery, M. C., Carvalho, M. L. M. de, \& Oliveira, L. M. de. 2007. Teste de tetrazólio para avaliação da qualidade fisiológica de sementes de melancia. Semina: Ciências Agrárias. 28(3):365-372. 
Nuraini, A., Saputri, R., Kadapi, M. \& Ruswandi, D. 2018. Correlations Between physical and physiological quality traits in mutant and non-mutant UNPAD sweet corn seeds after 4 months storage. 4th International Conference on Food and Agriculture Resources (FANRes 2018). Advances in Engineering Research. 172:165-168.

Panwar, A., Mishra, A.C. \& Negi, S. 2018. Correlation Studies on Seed Quality, Pod and Seed Yield in Germplasm of Pea (Pisum sativum L.). International Journal of Bio-resource and Stress Management. 9(1):098-102.

Paris, S. H., Tadmor, Y. \& Schaffer, A.A. 2017. Horticulture Production and Quality: Cucurbitaceae melons, squash, cucumber. Crop Systems. 2(3):209-216.

Pérez-Mendoza, C., Carrillo-Castañeda, G., Vidal-Lezama, E. y Ortíz-García, E. 2016. Efecto de la imbibición en la calidad fisiológica de semillas de jitomate. Revista Mexicana de Ciencias Agrícolas. 7(7):17651773 .

Poulsen, K. 2000. Análisis de semillas. En: Técnicas para la escarificación de semillas forestales. Programa de Investigación. Proyecto de semillas forestales (PROSEFOR)-Danida Forest Seed Centre. Costa Rica. 2 p.

SIAP. (2019). Servicio de Información Agroalimentaria y Pesquera. En línea: http://infosiap.siap.gob. mx:8080/agricola_siap_gobmx/ResumenDelegacion.do Consultado 20/03/2020.

Sologubik, C.A., Campañone, E.A., Pagano, A.M. \& Gely, M.C. 2017. Effect of moisture content on some physical properties of barley. Industrial Crops and Products. 43:762-767.

Souza, F. F., Queiroz, M. A. y Dias, R. C. S. 1999. Avaliação preliminar de híbridos experimentais de melancia sem sementes. Horticultura Brasileira. 17(3):330.

Suárez, D. y Melgarejo, L.M. 2010. Biología y germinación de semillas. In: Melgarejo, L. M. (ed). Experimentos en Fisiología Vegetal. Universidad Nacional de Colombia. Bogotá, Colombia. 13-24 pp.

Teixeira-Pinheiro, D., Leonir da Silva, A., Junio da Silva, L., Coelho-Sekita, M. \& Cunha Fernandes dos Santos Dias, D. 2016. Germination and antioxidant action in melon seeds exposed to salt stress. Pesquisa Agropecuária Tropical. 46(3):336-342.

Vera-Sánchez, K.S., Cadena-Iñiguez, J., Latournerie-Moreno, L., Santiaguillo Hernández, J.F., RodríguezContreras, A., Basurto-Pena, F.A., Castro-Lara, D., Rodríguez-Guzmán, E., López-López, P. y RíosSantos, E. 2016. Conservación y utilización sostenible de las hortalizas nativas de México. Servicio Nacional de Inspección y Certificación de Semillas (SNICS), México. 132 p.

Villa, F., Fernandes-da Silva, D., Copello-Rotili, M. C., Michelon-Herzog, N. F., \& Malvasi, M. (2019). Seed physiological quality and harvest point of dovyalis fruits. Pesquisa Agropecuária Tropical. 49(1):1-11.

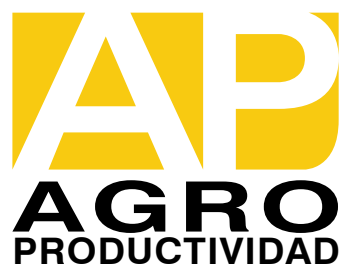

